\title{
38. Bir Ada Hikâyesi dörtlüsünde korku ve kaygının mekan ile ilgisi
}

\section{Mehmet Nevzat ARCAGÖK ${ }^{1}$}

APA: Arcagök, M. N. (2021). Bir Ada Hikâyesi dörtlüsünde korku ve kaygının mekan ile ilgisi. RumeliDE Dil ve Edebiyat Araştırmaları Dergisi, (24), 679-689. DOI: 10.2900o/rumelide.996984.

\section{$\ddot{\mathbf{O} z}$}

Bir Ada Hikâyesi dörtlüsü, Yaşar Kemal'in nehir roman tarzında yazılmış dört kitaplık eseridir. Firat Suyu Kan Akıyor Baksana, Karıncanın Su İçtiği, Tanyeri Horozları ve Çıplak Deniz Çıplak Ada romanlarından oluşan dörtlüde Lozan Barış Antlaşması'na ek olarak Türkiye ile Yunanistan arasında 30 Ocak 1923'te imzalanan mübadele sözleşmesinin sebep olduğu bazı psikolojik ve sosyal sorunlar, yerlerinden edilmiş insanların yeni yerleştikleri yerlerde yaşadıkları korku ve kaygıları işlenmektedir. İnsanın yıllarca yaşadığı coğrafyadan, evlerinden ayrılmak zorunda kalmaları, yeni yerleştirildikleri yerlere uyum sağlamaları zorlu bir süreç gerektirir. Başka bir yerde hayat kuran insan, en azından başlarda yoğun bir şekilde kaygı duygusu yaşayacaktır. Kaygı, yeni yerleşilen yerde yaşanması muhtemel adaptasyon (uyum) problemlerinden kaynaklanır. Sözünü ettiğimiz problemlerin yanında göç edilen mekânın gelenek ve göreneği, kültürü, yaşam tarzı vs. sayamayacağımız birçok unsur göçmenlere yabancı oldukları gerçeğini hatırlatmaktadır. Özellikle de yaşanılan göç olayı birey veya toplumların elinde olmayan nedenlerden dolayı kendi iradeleri dışında gerçekleşmişse göçe maruz kalan toplulukta aynı zamanda geçmişe duyulan özlem ve bir an önce eski hayata ve düzene geri dönme isteği kendisini gösterecektir. Siyasi antlaşmalarla zorunlu göçe tabi tutulan göçmenler, geride bıraktıkları her şeye bir özlem duygusuyla yaklaşırlar. Yurt özleminin yanında göç eden kişiler sevdiklerinden ve yaşadığı mekânlardan ayrılmanın hüznüyle yaşam sürerken bu durum çalışmamızda da görüleceği üzere kimi korku ve kaygıların da kapılarını aralamaktadır.

Anahtar kelimeler: Korku ve kaygı, mekân, göç

\section{The relationship of fear and anxiety with the setting in the tetralogy titled Bir Ada Hikâyesi}

\begin{abstract}
The tetralogy of Bir Ada Hikayesi is Yaşar Kemal's four-book work written in the river novel style. In addition to the Lausanne Peace Treaty, some psychological and social problems caused by the exchange agreement signed between Turkey and Greece on January 30, 1923, the fears and anxieties that deterritorialized people experience in their new settlements are narratedin the tetralogy of Furat Suyu Kan Akıyor Baksana, Karıncanın Su İçtiği, Tanyeri Horozları and Çıplak Deniz Çıplak Ada. It is a difficult process for people to have to leave their homeland and homes where they have lived for years and to adapt to their new places of residence. A person who makes a life there will experience anxiety deeply at least at the first stages. Anxiety stems from possible adaptation problems in the newly settled place. In addition to the problems we mentioned, many factors such as the customs and traditions, culture, lifestyle etc. of the place of migration that we can not count remind the immigrants of the fact that they are foreigners. In particular, if the migration event occurred outside of their own will due to reasons beyond the control of individuals or societies, the longing for the past and the
\end{abstract}

Doktora, İstanbul Medeniyet Üniversitesi, Sosyal Bilimler Enstitüsü, Türk Dili ve Edebiyatı (İstanbul, Türkiye), mehmetnevzatarcagok@hotmail.com, ORCID ID: oooo-0oo3-3985-3118 [Araştırma makalesi, Makale kayıt tarihi: 09.08.2021-kabul tarihi: 20.09.2021; DOI: 10.29000/rumelide996984]

Adres | Address

RumeliDE Dil ve Edebiyat Araştırmaları Dergisi Osmanağa Mahallesi, Mürver Ciçeği Sokak, No:14/8 Kadıköy - İSTANBUL / TÜRKIYE 34714 e-posta: editor@rumelide.com

RumeliDE Journal of Language and Literature Studies

Osmanağa Mahallesi, Mürver Çiçeği Sokak, No:14/8

Kadıköy - ISTANBUL / TURKEY 34714

tel: +90 505 7958124, +90 2167730616

e-mail: editor@rumelide.com,

phone: +90 5057958124 , +90 2167730616 


\begin{abstract}
desire to return to the old life and order as soon as possible will show itself in the community exposed to the migration. The immigrants who are forced to migrate by the political treaties approach everything they leave behind with a sense of longing. While immigrants live with the sadness of leaving their loved ones and the places where they live, this situation also opens the doors of some fears and anxieties, as can be seen in our study.
\end{abstract}

Keywords: Fear and anxiety, place, migration

\title{
Giriş
}

İnsanoğlu tehlike karşısında korkar, belirsizlik karşısında ise kaygı duyar. Her iki tepki, bireyin nefes alıp vermesinden konuşmasına, tavır ve davranışlarına kadar yansır. İnsan, hayatı boyunca az veya çok korku ve kaygı duygularını yaşar. İlk bakışta olumsuz gibi görünse de, belli düzeyde kalması şartıyla bunların bireyin yaşamını koruması açısından önemli, hatta lüzumlu olduğu bile söylenebilir. Ancak, tepkiler aşırılaşır; yaşama’yı deneyimleyeceği alanı ördüğü duvarlarla daraltacak seviyeye yükselirse bu durum bir hastalık'a da dönüşebilir. İnsanlıkla yaşıt bu duygular, tabiidir ki kurmaca metinlerde de karşımıza çeşitli olay örgüleri arasında çıkar. Gerçek hayatta olduğu gibi, kurmaca metinlerde de karakterler bu duygulara maruz kaldıklarında çeşitli tepkiler ortaya koyarlar. Bu manada bazen aynı olaya maruz kalan farklı bireyler, mizaçlarına göre korku ve kaygı duygularının birini veya her ikisini birden yaşarken, bazı karakterler geri çekilmek, sinmek yerine kendilerine yönelen belirli veya belirsiz tehdit unsurunun üzerine gider; onları bir şekilde aşarak yaşamasını sürdürmek için çaba gösterir.

Bu çalışmamızda göç olgusunun bir sonucu olarak ortaya çıkan bir korku üzerinde; yabancı mekân korkusu üzerinde durmaya çalışacağız. Göç, bireysel ya da toplu olarak, kimi zaman isteyerek bazense bir zorunlulukla gerçekleştirilen yer değişikliğidir. Özellikle savaşlarda meydana gelen kitlesel veya bireysel göçlerde toplumun veya bireyin özgür seçimi söz konusu değildir. Göçe zorlandıkları bilmedikleri yerlerde yaşamak zorunda kalmak, tanımadıkları bir çevreye yerleşmek, insanda bazen korku, çoğunlukla da kaygı yaratacaktır. Yaşar Kemal'in Bir Ada Hikâyesi dörtlüsünde göçe zorlanan farklı etnik grupların önce yaşadıkları yerden ayrılmak istememeleri, göç ettirildikleri adada yaşayan insanlarla kaynaşana kadar yaşadıkları çeşitli uyum sorunları, ülkelerine geri dönme arzuları dramatik biçimde anlatılmıştır.

\section{Korku ve kaygı}

Korku, belli bir tehlike karşısında kişinin yaşadığı ruhsal tedirginlik, üzüntü, kendisine zarar gelebileceğine dair duymuş olduğu yıkıcı bir duygudur. Kaygı ise bireyin izah edemediği bir belirsizlikle karşı karşıya olduğunu düşünmesinden doğar. Kesici bir aletle kendisine yaklaşıldığını gören biri korkar. Çünkü tehdit nesnesi ve istikameti bellidir. Kaygıda ise böyle bir açıklık söz konusu değildir.

"Korku ve kaygı arasında yapılan genel bir ayrım, tam da korkunun belli bir nesnesi varken kaygının bundan yoksun olmasına dayanır" (Svendsen, 2017: 49).

Kaygı, sözgelimi sınav, iş görüşmesi veya yapacağı herhangi bir sosyal etkinlik öncesinde bireyin bunların sonuçlarına yönelik hissettiği belirsizliğin sebep olduğu huzursuzluk durumudur. Böylesi durumlarda tehdit açık değildir. Buna göre akla şöyle bir soru gelebilir: "Birey korku ve kaygı duygusunu aynı anda yaşar mı?” Elbette bu iki duygu aynı anda yaşanabilir. Mesela araba kullanmayı öğrenen sürücü adayı, direksiyon başına geçtiğinde ilk önce tedirginlik ve endişe durumlarını yaşar. Sürücü adayının o sırada aklından bir kaza sonucu öleceğini düşünmesi ise onda korku duygusunu yaratır.

\footnotetext{
RumeliDE Dil ve Edebiyat Araştırmalar Dergisi Osmanağa Mahallesi, Mürver Ciçeği Sokak, No:14/8 Kadıköy - İSTANBUL / TÜRKIYE 34714 e-posta: editor@rumelide.com tel: +90 505 7958124, +90 2167730616 
Çünkü, bu ihtimal fiziksel tehditle ilgilidir. Fakat yaşanan kaza sonucu herhangi bir zarar görmeden kurtulduğunda toplumun onu acemi şoför olarak küçümsemesi düşüncesi onda kaygı duygusuna yol açar.

Korku ve kaygı durumları, benzer psikolojik ve fizyolojik tepkilerle açığa çıkar: Damarların genişlemesi, kan basıncının artması, kalp atışının hızlanması, soğuk terleme, göz bebeklerinin büyümesi, kas gerginliği, baş ağrısı, ağız kuruluğu, sık idrara çıkma, mide ve bağırsak sorunları vs. Yukarıda verdiğimiz örneği takip edersek, sürücü adayı korku ve kaygı duygusunu aynı anda yaşarken fizyolojik olarak bu belirtilerden birkaçını gösterebilir. Dolayısıyla bunlardan yola çıkarak onun korku veya kaygı duygularından hangisini tam olarak yaşadığını kestirmek güçtür. Korku duygusunu tüm canlılar yaşar; ancak kaygı, sadece insanlarda görülür. Hayvanlar her ne kadar akıl, duygu ve düşünceleriyle hareket etmeseler de canlarını koruma içgüdüsüyle herhangi bir tehlikeyle karşı karşıya kaldıklarında korku duygusunu yaşarlar. Canlı varlığın bir gün eceliyle öleceği düşüncesi, insanoğlu dışındaki canlı varlıklarda görülen bir özellik olmadığı için hayvanlar korkuya -özellikle ölüm korkusuna- insanlar gibi bilinçli bir anlam atfetmezler.

"Kaygı kavramına psikolojide hemen hemen hiç değinilmemiştir. Bu terimin korkudan ve korkuya bağlı, belirli bir nesnesi olan benzer kavramlardan tümüyle farklı olduğunu belirtmeliyim. Kaygı bu nedenle hayvanda bulunmaz; çünkü tin, hayvana yüklenmiş bir nitelik değildir" (Kierkegaard, 2017: $35)$.

Hayvanların içgüdüleriyle yaşamaları kaygı duygusunu yaşamamalarının bir nedenidir. Geleceğe yönelik planları, umut ve beklentileri olmadığı için de yaşayacakları bir belirsizlik hâli, kaygı durumu da söz konusu olamaz.

\section{Romanda mekân}

Mekân, romanlarda olayların geçtiği ve aynı zamanda karakterlerin duygu ve düşüncelerini ifade etmelerine olanak sağlayan yerdir.

"Mekân, romana özgü olay ya da olayların ve roman kişilerinin hareketlerine ayrılmış bir sahne olan yerdir" (Çetin, 2019: 135).

Romanda mekân, değişik amaçlarla kullanılabilir. Olayların yaşandığı çevreyi ve sosyal ortamı tanıtmak, roman kahramanlarına hayatiyet kazandırmak, atmosfer yaratmak bu nedenlerden bazılarıdır. Öte yandan, diğer materyal unsurları gibi mekân da romana gerçeklik havası katmak amacıyla kullanılır. Gerçek yaşamda da bizler açık ve kapalı mekânlar içerisinde yaşamaktayız. Bağlı bulunduğumuz çevreyle özdeşleşmişizdir. Toplumsal hayatta çevremizde olup bitenler bizi etkilediği gibi bizler de zaman zaman çevremizi çeşitli seviyelerde anlamlandırmaktayız. Doğal olarak çevre ile insan arasında sıkı bir ilişki söz konusudur. Romanda yaratılan mekânlar bireyin psikolojisini yansıttı̆̆ gibi onun duygu ve düşüncesine göre de şekillenmektedir.

"... Anlatı türlerindeki mekân kurgusaldır ve içinde yaşayan insanların bakış açıları, algı kapasiteleri ve duyusal gelişmeleri doğrultusunda şekillendirilmiştir..." (Korkmaz-Şahin, 2017: 10).

Mekân, sadece insanların yaşadığı ortam olarak algılanmamalı. Bu mekânı çevreleyen dekor, eşya, buna bağlı maddi ve manevi değerler mekânla birlikte romanlarda ele alınan unsurlardır. Dönemin kültürel ve geleneksel özellikleri, kostümleri ve konuşma tarzları da dâhil olmak üzere mekânı bütünleyecek biçimde oluşturulur. Kurmaca yazarı anlattığı olayı uygun bir mekâna oturtmalı, şahısları bu mekâna

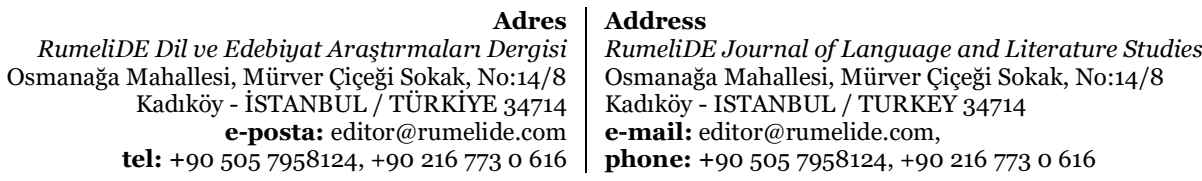


uygun olarak konuşturmalı ve bununla da yetinmeyerek iç ve dış mekânı metnin diğer unsurlarıyla uyumlu olarak vermelidir.

"Kişi oluşturmuyorsunuz o zaman gerçek roman yazmıyorsunuz, bir hikâye anlatmıyorsunuz, o zaman gerçek roman yazmıyorsunuz, tutkuları da çözümlemiyorsunuz, o zaman gerçek roman yazmiyorsunuz" (Robbe-Grillet, 2015: 114).

Roman öncesi türlerde de mekân söz konusudur; ancak oluşturulan mekân sadece kişilerin içinde bulunması zorunlu bir yer olabildiği gibi, silik, betimlenmesi amacıyla verilmiş hayali bir yerdir. Mekânların gerçek hayatta olup olmaması roman öncesi türler için pek önemli değildir. Bu nedenle mekân bir iki cümle ile geçiştirilerek aktarılır ve olaya geçilir. Roman türü ile birlikte artık mekân diğer materyal unsurlar kadar önem kazanmıştır. Geleneksel romanlara baktığımızda anlatı daha çok hakim (Tanrısal) bakış açısı ile oluşturulduğundan yazarın her şeyi bilen, gören, duyan ve her şeye hakim bir tarzda mekânı yansıttığı görülür. Geleneksel romanların yerini modern romanlara bırakması ile artık kahraman anlatıcının bakış açısı ile romanlar oluşturulunca mekânın tanıtımı, çizimi ve yansıtılması da kahramanın gözüyle olmuştur. Yani roman kahramanı kendi bilgisi, kültürü, psikolojisi doğrultusunda mekânı ile özdeşleşmiştir.

"Çağdaş romanda, anlatıcının veya bir kahramanın gözüyle dış mekân anlatılır ve bu mekân tasviri, tasvir ettiği objelere verdiği duygularla, meydana gelmektedir" (Ayylldız, 2011: 105).

Yine aynı mekân farklı roman şahısları tarafından farklı biçimde algılanır. Başka bir deyişle romandaki her karakter kendi bakış açılarıyla mekâna yaklaşmaktadır. Örneğin bir hırsız ile bir misafirin aynı apartman dairesine yaklaşımları farklı olur. Çünkü her iki şahıs aynı dünyaların insanı olmadığı gibi aynı düşünceyle mekâna yaklaşmamaktadır. Bu durum şahsın mekâna nasıl bir duyguyla yaklaştı̆̆ının göstergesidir. Romanlarda mekân, şahıslar üzerinden duygusal bir boyutta karşımıza çıkabilir.

"Önemli olan şahsın mekânı yaşayış veya algılayış biçimidir" (Tepebaşılı, 2019: 11).

Geleneksel roman anlayışı yerini modern romana bırakınca artık mekân da bireyle özdeşleştĭgi gibi bireyin içinden geçenleri yansıtan bir araç hâline gelmiştir.

"20. yy.da büyük bir değișim yaşanmıș ve çağdaș romancılar, romanın unsurlarına yeni boyutlar kazandırmışlardır. Mekânın işlevi değişmiş; mekân, gerçeği olduğu gibi yansıtmak veya değiştirmek yönünde kullanılmıştır. Mekân, dış gerçekliğin değil, iç gerçekliğin yansıtılmasına vasıta olmuş, insanın bilinç dünyasının aydınlatılması esas alınmıştır" (Ayyıldız, 2011: 100-101).

Mekân, anlatıcı tarafından tanıtılırken betimleme (tasvir) tekniği kullanılır. Çevre tasvir edilerek aktarıldığı gibi romanda olaylar zincirinin oluşumunda ve aksiyonlaşmasında aktif rol oynar. Böylece olaylar zinciriyle merak öğesi ön plana çlkarken karakterlerin duygu, düşünce ve davranışları da harekete geçer. Romancı kendince bir dünya yarattığı için o dünyanın okuyucuda izlenim ve imaj oluşturması için ister istemez tasvir tekniğine başvurur. Ayrıca betimleme romanda değişik amaçlarla kullanılır. Kimi zaman okuyucuya bir mesaj verir, kimi zaman olayların geliştiği dönem ve ortamın siyasi, sosyal görünümü hakkında okuyucuyu bilgilendirir, kimi zaman da okuyucuda estetik zevk uyandırmak için betimleme tekniği kullanılır.

"Betimlemeye uzun süre estetik bir işlev atfedilmiştir. Antikçă̆'ın daha başından itibaren, açıkça işlevsel bir kullanımı olan hukuksal ve siyasal söylemlerin yanı sıra, üçüncü bir tarz, dinleyiciyi inandırmayı değil, onda hayranlık uyandırmayı amaçlayan gösterişli bir söylem geliştirilmiş; dilin estetik bir amaca hizmet edebileceği fikri doğmuştu..." (Watt-Barthes, 2006: 52).

RumeliDE Dil ve Edebiyat Araşttrmaları Dergisi Osmanağa Mahallesi, Mürver Ciçeği Sokak, No:14/8 Kadıköy - ISTANBUL / TÜRKIYE 34714 e-posta: editor@rumelide.com tel: +90 $5057958124,+902167730616$
Address

RumeliDE Journal of Language and Literature Studies

Osmanağa Mahallesi, Mürver Çiçeği Sokak, No:14/8

Kadıköy - ISTANBUL / TURKEY 34714

e-mail: editor@rumelide.com,

phone: +90 505 7958124, +90 2167730616 
Mekân, romanlarda karakterlerin iç dünyalarını ve arzularını dışa yansıtmak amacıyla kullanılmaktadır. Bu nedenle ruhen tedirgin, korku ve kaygı dolu bir psikolojiye sahip karakterin içinde bulunduğu mekân bunlara uygun olarak karanlık, çalkantılı ve ürkütücü bir manzarayla çizilir. Tersi bir durumda, yani neşeli ve güler yüzlü bir karakterin yaşadığı psikolojiye uygun olarak da mekân gün veya güneş ışığından yararlanılarak aydınlık, sevinç ve huzur verici bir tarzda çizilir.

\section{Göç olgusu}

Göç olgusunun temelinde çeşitli faktörler yer alır. Ekonomik, sosyal, kültürel, sağlık, ailevi ve siyasi nedenlerden dolayı göçler gerçekleştiği için göçün sadece tek bir tanımı olmadığı gibi göçle ilgili birçok kuram ve tasnifle karşılaşırız.

"Göç; bireylerin, grupların, toplumların algılarındaki değişim ile başlayan, mekânda yer değiştirme ile devam eden ve varılan yere uyumla tanımlanan süreçler bütünü olarak değerlendirilmektedir" (Battır, 2020: 8).

Yukarıda ifade ettiğimiz gibi göçe neden olan tek bir faktör olmadığı gibi yapılacak tanımlar da göçün farklı özelliklerine işaret eder.

"...Göç, bireysel, ekolojik, iktisadi yahut siyasi sebeplerden hareketle, yaşanılan yerden başka bir yere gerçekleştirilen, kısa veya uzun süreli coğrafi, toplumsal ve kültürel değişimi içeren bir nüfus hareketidir" (Yaman, 2018: 20).

Bu nedenle göç, bir topluluğun çeşitli sebeplerden dolayı yaşadığı çevreden başka bir çevreye gitme eylemine karşılık geldiği için aynı zamanda sosyal bir hareketliliktir. Göç olgusunu daha detaylı ele aldığımızda farklı göç tipleri karşımıza çıkar. Ancak konumuz sınırları içerisinde değerlendirdiğimizde göç, nüfus hareketini sağlayan faktörlere göre; serbest ve güdümlü olmak üzere ikiye ayrllır. Serbest göç; bireylerin mali olanaklar, iş imkanları, eğitim vs. çeşitli sebeplerden dolayı daha iyi hayat şartları içerisinde yaşamak amaciyla kendi özgür iradeleriyle serbestçe yer değiştirmeleridir. Güdümlü göç ise; devletlerin sosyal, ekonomik, güvenlik vs. gerekçelerle aldıkları birtakım kararları hayata geçirmeleri sonucunda yarattıkları nüfus hareketliliğidir (Akkayan, 1979: 23-24). Güdümlü göç, bireyin isteği veya arzusu dışında zorunluluk esasına göre yapılmaktadır.

Göç tekil olduğu gibi kimi zaman geniş bir topluluk kitlesini kapsar ve bu türden yapılan göçler de genelde zorunluluktan kaynaklanır. Bu zorunluluğun başında deprem, doğal afetler, yangın, kuraklık, salgın hastalıklar ve uluslararası antlaşma ve sözleşmeler gelmektedir.

"Tarihin farklı dönemlerinde göçe sebep olan unsurlar, açlık, kıtlık ve doğal afetler gibi bazen çevresel, bazen de siyasi baskı ve savaş gibi zorlayıcı etmenler olabilmektedir" (Yaman, 2018: 15).

Zorunlu yapılan göçlerde bireyler, içinde bulunulan mekânın iticiliği ve gidilecek olan hedef mekânın çekiciliği gibi hususları göz önünde bulundurmaz. Yapılacak olan göç irade dışı yapıldığından göçe tabi tutulan bireyler daha çok yerleşecekleri bölgelerde nasıl bir yaşam sürecekleri hususunda kaygılıdırlar. Göç yalnızca bir coğrafi değişiklik olmadığı için psikoloji, sosyoloji, ekonomi, hukuk, uluslararası ilişkiler, siyaset, vs. birçok bilim dalının inceleme alanına girmektedir. Dolayısıyla göç kavramını çalışmamızda konumuz itibariyle ele alarak incelemeye çalışacağız.

\begin{tabular}{r|l} 
Adres & Address \\
RumeliDE Dil ve Edebiyat Araştırmaları Dergisi & RumeliDE Journal of Language and Literature Studies \\
Osmanağa Mahallesi, Mürver Çiçeği Sokak, No:14/8 & Osmanağa Mahallesi, Mürver Çiçeği Sokak, No:14/8 \\
Kadıköy - İSTANBUL / TÜRKIYE 34714 & Kadıköy - ISTANBUL / TURKEY 34714 \\
e-posta: editor@rumelide.com & e-mail: editor@rumelide.com, \\
tel: +90 505 7958124, +90 216773 o 616 & phone: +90 505 7958124, +90 216773 o 616
\end{tabular}




\title{
Bir Ada Hikâyesi dörtlüsünde göçün neden olduğu mekânsal korku ve kaygı
}

Bir Ada Hikayesi dörtlemesinin ilki Furat Suyu Kan Akıyor Baksana'da Lozan'a ek olarak Türkiye ile Yunanistan arasında imzalanan mübadele sözleşmesi gereğince Yunanistan'daki Türkler ile Türkiye'deki Rumların karşılıklı olarak mübadelesi ele alınmaktadır.

\begin{abstract}
"Yapılan görüşmeler sonucunda, 30 Ocak 1923'te imzalanan sözleşme ve protokol ile Türk ve Yunan nüfus değişimi yani mübadele uygulamaya konulmuş ve 1 Mayıs 1923'ten itibaren değişim başlamıştır. Buna göre, Türkiye'de yerleşmiş (etabli) Rum Ortodoks dininden olan Türk tebaa ile, Yunan topraklarında yaşamış Müslüman Yunan tebaanın yer değiştirmesi kararlaştırılmış, İstanbul Rumları ile Batı Trakya Müslümanları bundan muaf tutulmuştur" (Yönlü, 2018: 119).
\end{abstract}

Yapılan antlaşmalar gereği, zorunlu olarak göçe tabi tutulan toplulukların bir bakıma yer ve yurtlarından ayrı kaldıkları için geride bıraktıkları her şeye duydukları özlem, yaşayacakları dramatik hayatın en önemli nedenlerinden biridir. Böylesi bir topluluk, antlaşma gereği uygulanan mübadeleyi, yaşadıkları olaylara bakarak bazen sürgün olarak da adlandıracaklardır.

Uzun süre belli bir coğrafyada yaşam süren topluluk, o coğrafyaya veya bölgeye her açıdan uyum sağlayarak yaşamaktadır. Bu topluluğun göçe zorlanması, ister istemez onlarda kaygıya neden olur. Göç edilecek bölgeyi bilmemek, çevrenin ve o çevreye bağlı topluluğun nasıl bir yapıya sahip olduğuna yönelik belirsizlikler, bu kaygıyı büyüten en önemli sebeplerden sadece birkaçıdır. Belli bir coğrafyada yaşamış topluluk o bölgenin kültürünü, gelenek ve göreneklerini, yaşam biçimini ve hatta dilini de özümsemiştir. Bir toprak parçasını vatan yapan, belki de saymış olduğumuz unsurlardır. Bu unsurlara alışmış topluluk bir anda farklı kültür, dil, din ve belki de sayamadığımız birçok kaygı üreten faktörlerle karşlaşacaktır.

"Göçmenler yeni bir ülkeye gittiklerinde, o güne kadar bildiklerinden farklı mekânlardan ve insanlardan oluşan yeni bir sosyal ve kültürel çevreye girmekte, iletişimin temel kurallarının, biçimlerinin farklı olduğu bir dille karşılaşmaktadır" (Yalçın, 2017: 61).

Firat Suyu Kan Akıyor Baksana'da Karınca Adası'nın boşaltılacağı ilk başlarda bir söylenti olarak dolaşır. Adalılar bu habere bir türlü inanmak istemezler. Daha sonra jandarma yüzbaşısının adanın sorumlusu olarak bilenen Milto'ya resmi yazıyı okumasıyla Rumlar mübadele gerçeğini istemeseler de kabul etmek zorunda kalırlar. Adalılar evlerini ve kendilerine ait mal mülklerini bırakıp gitmenin kaygısı içindedir. Rumlar gelen teknelere binerek adayı terk eder; ancak içlerinden Vasili, İstanbul kütüğüne kayıtlı olduğundan mübadeleden etkilenmez, adada kalır. Tek başına yaşamayı göze alacak kadar yaşadığı mekânı seven Vasili, bu adaya ayak basacak ilk kişiyi de öldürmeye yeminlidir.

Karınca Adası ıssız, terk edilmiş, kimsenin yaşamak istemeyeceği bir yer olarak karşımıza çıkar. Öyle ki adanın perili olduğu ve kimsenin korkudan buraya yaklaşmak istemediği bazı karakterler aracılı̆̆ıyla yansitılmaktadır (Firat Suyu Kan Akıyor Baksan, 2019: 48).

İlerleyen zamanlarda asıl adı Abbas olan ve I. Dünya Savaşı'nda düşmanla çarpışmış, tedbir amaçlı ismini Poyraz Musa olarak değiştirmiş karakter bu adadan bir ev ile değirmen satın alır ve orada yaşamaya başlar. Poyraz Musa, zaman zaman adada insana benzeyen bir karartıya denk gelir ve bu karartının bir insan olduğunu anlayınca burada kendisi dışında birilerinin yaşadığına kanaat getirir. Bu karartı Vasili'dir. O, buraya gelen ilk kişiyi öldüreceğine yemin etmiş olsa bile Poyraz Musa'yı öldüremez.

Poyraz Musa adadayken yerleşmek amacıyla bazıları burayı ziyaret eder. Ziyaretçilerden biri, Yunanistan'dan Türkiye'ye göç ettirilmiş olan Ali Paşa Selim Bey'dir. Geldiğinde Poyraz Musa ile

\footnotetext{
Adres | Address

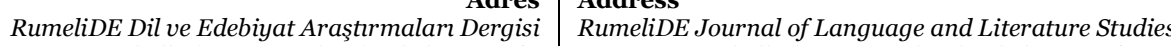

Osmanağa Mahallesi, Mürver Çiçeği Sokak, No:14/8 $\quad$ Osmanağa Mahallesi, Mürver Çiçeği Sokak, No:14/8

Kadıköy - İSTANBUL / TÜRKIYE 34714 Kadıköy - ISTANBUL / TURKEY 34714

e-posta: editor@rumelide.com e-mail: editor@rumelide.com,

tel: +90 505 7958124, +90 2167730616 phone: +90 505 7958124, +90 2167730616
} 
tanışmış, adayı beraber gezmişlerdir. Ancak burada kimsenin yaşamadığını gördüğünde teknesine atlayarak geri döner.

Adaya gelenlerden bir başkası Veteriner Hekim Cemil'dir. O da metruk bir adada yaşamayacağına karar verip ayrılmıştır. Emekli asker Doktor Selman Sami'nin ise Poyraz Musa ile adayı dolaştıktan sonra içine bir ağırlık ve hüzün çökmüştür. Bu tenhalık onu adeta boğar. Düşüncelerini de zaten Poyraz Musa'ya açıklamıştır:

"Çok rica ederim. Ben, burada biraz daha kalırsam ölürüm. Çok çok rica ederim. Duramam, duramam. Of, of, of, ooof Poyraz Bey oğlum, öleceğim, öleceğim, dayanamıyorum. Beni atın kayığınıza, götürün kasabaya. Ben oradan İstanbul'a giderim. Kabus efendim, kabusu kebir. Beni buradan kurtarın, kurtarı!!" (Firat Suyu Kan Akıyor Baksana, 2019: 216).

İnsanoğlu korkuları sebebiyle yalnız yaşamak istemez. Yalnızlık, can sıkıntısı ve en önemlisi de bir tehlike sırasında sığınılacak kimsenin olmaması kişide kaygıya neden olur. Adayı ziyarete gelenlerin buradan hemen ayrılmalarının sebebi de burada aranmalıdır.

Vasili, özellikle emekli asker Doktor Selman Sami'nin adayı terk etmesini pek anlayamaz. Onu korkak bir asker olarak nitelendirir (Firat Suyu Kan Akıyor Baksana, 2019: 219).

Dörtlünün ikinci serisi Karıncanın Su İçtiği'nde adaya Girit'ten göç ettirilmiş Musa Kazım Ağa ve kızları gelir. Kazım Ağa, Poyraz'la tanışır; göç ve mekâna dair sohbet ederler. Daha önce de belirttiğimiz gibi göçe tabi tutulanlar, kaygı duygusuyla iç içe yaşar. Çünkü, yerinden yurdundan ayrı kalmışlar, yeni yerleştikleri yer ise onlar için bilinmezliklerle doludur. Kazım Ağa, göçe dair şunları söyler:

"Bu çok büyük haksızlık. Bu, insanlığa yakışmaz. Buna, düpedüz sürgünlük derler. Buna işkence, buna zulüm derler.

(...)

Bir insanı yurdundan koparmak, o insanın yüreğini koparmaktan daha çok acı veriyor." (Karıncanın Su İçtiği, 2018: 187).

İnsanoğlu yurduyla kendini özdeşleştirdiği için vatanına ait olma duygusu içerisinde yaşam sürer. Bu bir bakıma bireyin gereksinim duyduğu aidiyet ihtiyacıdır. Ülkesinde mutlu, huzurlu ve güven içinde yaşam süren topluluk ansızın zorunlu olarak göçe tabi tutulduğunda belki de kendisini güvende hissedemeyeceği bir ortamda yaşamak zorunda kalır. Bu durum göçmenlere yaşayacakları gurbet hasretiyle birlikte acı veren kimi olumsuz duygulara neden olur. Belirtmeye çalıştı̆̆ımız husus, romanda Kazım Ağa örneğiyle belirginleştirilmiştir.

Romanda mübadiller ve savaş nedeniyle yersiz yurtsuz kalmış aileler adaya gelmeye başlar. Özellikle Poyraz Musa, Vasili ve Lena adaya gelenlere yardımcı olur. Ellerinden geldiğince onların temel geçim malzemelerini sağlamaya, barınma ihtiyaçlarını gidermeye çalışırlar. Zaman zaman da hep birlikte kasabaya inerek birtakım ihtiyaçları ailelerle beraber karşılarlar. Adaya gelenler daha önce hangi işle meşgul olmuşlarsa aynı işi imkan buldukça burada da onu yapmaya çalışırlar. Ada gün geçtikçe kalabalıklaşır, şenlenir. Gelenler, adadakilerin yardımsever ve iyi niyetli olduklarını gördükçe onlarla çabucak kaynaşırlar. Hatta daha önce beğenmeyip ayrllanlar da dönerler.

"...Bu cennet adasını beğenmeyip geri gittik ya, ben döndüm dolaştım, gezdim gördüm, kendi kendime, acımdan da ölsem, altı kızım, bir de ben, bir de karım, ben bu güzel adada öleceğim, dedim, döndüm." (Karıncanın Su İçtiği, 2018: 48).

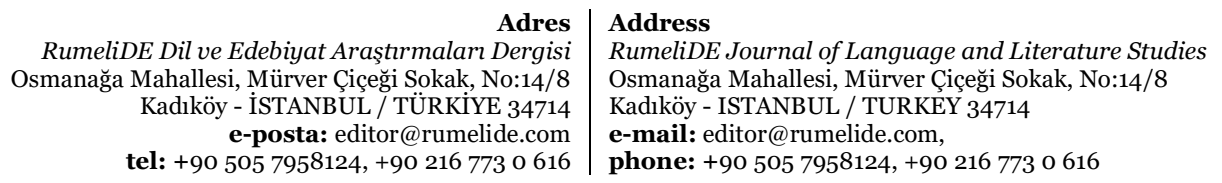

tel: $+905057958124,+902167730616$ 
Daha önce adayı ıssız, dört bir yanı denizle çevrili ve her yere uzak bir mekân olarak gören ve bundan korkan Hüsmen, ikinci gelişinde insanların orayı şenlendirdiğini gördükten sonra fikri değişmiştir. Askerlik yapmış Doktor Salman Sami de bir süre sonra kendisi gibi asker Doktor olan Halil Rifat adında arkadaşıyla adaya tekrar geldiğinde düşünceleri farklılaşmıştır:

"Sanıyorum ki hiç sıkılmayacağım. Ömrümü bu adada bu güzel insanlar arasında bitireceğim.

(...)

Bu ada güzel bir ada, cennetten bir köşe, bu adayı onlar güzelleştiriyorlardı. Burada birlikte, insan sıcaklığını, tabiat sıcaklı̆̆ıı birlikte yaşamaya geldim." (Karıncanın Su İçtiği, 2018: 482-485).

Göçe tabi tutulan topluluk ile yerli halk arasındaki dayanışma ve yardımlaşma arttıkça göçün neden olduğu sıkıntılar da bir nebze azalmaktadır. Aynı zamanda bir arada yaşama isteği bireyin sosyal çevresine uyumunu sağlayan önemli bir unsurdur. Bir mekân, orada yaşayanların dostluğu, samimiyeti, sıcaklığı ve insanlığı ile rağbet görür. Bu nedenle karakterlerin Karınca Adası hakkındaki düşünceleri değişmektedir.

Göze çarpan diğer bir husus, bireylerin aynı mekâna yaşanan gelişmelerden dolayı farklı bir gözle yaklaşmalarıdır. Bunun temelinde insanoğlunun olay ve durumlara atfettiği anlam yatmaktadır. Daha önce de ifade ettiğimiz gibi aynı mekân her insanda her zaman aynı düşünceleri veya anlamları doğurmayabilir. Bu durum insanoğlunun yaşadığı mekânı hangi gözle gördüğü ve algıladığı bakış açısıyla ilgilidir.

Girit'ten Türkiye'ye göç ettirilmiş olan Musa Kazım Ağa Efendi adada kızlarıyla mutlu bir yaşam sürse de vatan hasreti yaşar. Bu vatan hasreti ve özleminin de bir gün biteceğine ve ülkesine tekrar geri döneceğine yönelik ümidi hiçbir zaman bitmez.

Dörtlünün üçüncü serisi Tanyeri Horozları'nda vatan hasretiyle yanıp tutuşan Kazım Ağa Efendi, Lena'nın Yunanistan'ı terk ederek Türkiye'ye gelişini de imrenerek dile getirir:

"Yaşasın Lena, kaçtı da adasına geri geldi. Adasında rahat ölecek, gözü açık gitmeyecek. Ben de Girit’e döneceğim, ölürken gözüm açık gitmeyecek." (Tanyeri Horozları, 2019: 38).

Musa Kazım Ağa Efendi, vatanına tekrar dönme uğruna hatırı sayılır eş ve dostlarını devreye sokmaya çalışır. Öncelikle Poyraz Musa'nın tanıdı̆̆ı, önceden cephelerde savaşmış ve daha sonra da milletvekili olarak meclise girebilmeyi başarmış eski komutanıyla görüşürler. Görüşmenin özü, Kazım Ağa Efendi'yi ülkesine tekrardan iade edebilmektir; ancak komutan hakaret dolu sözlerle bu isteği reddeder. Kazım Ağa Efendi yine vazgeçmez; dostu Sait Rahmi'yi devreye sokmaya çalışır. Sait Rahmi'nin babası nüfuzlu bir milletvekilidir. Babası emekli olduktan sonra oğlu milletvekilliğine aday olmayı düşünmektedir. Sait Rahmi konuyu dostu Yunan Sefiri'ne açar; ancak o da bu işin zor olduğunu, yine de konuyla ilgileneceğini ifade eder. Zaman içinde girişimlerinden bir sonuç alamayan Kazım Ağa Efendi'nin psikolojisi olumsuz yönde etkilenir. Yine de ümidini kaybetmek istemez. İlerleyen zamanlarda Yunanistan'da tutuklu olan general arkadaşından mektup alır ve mektupta da serbest bırakıldığı takdirde ilk işinin onun tekrardan ülkesine dönmesini sağlamak olacağı söylenmektedir. Bu haber Kazım Ağa Efendi'yi sevince boğar. Musa Kazım Ağa Efendi'nin yurduna dönme isteği serinin dördüncü cildinde de devam eder.

Romanda sadece Yunanistan'dan göç edenler değil aynı zamanda Anadolu'nun çeşitli yerlerinden savaş nedeniyle göç etmek zorunda kalmış fakir halka da rastlamaktayız. "Anadolu muhacirleri" diye

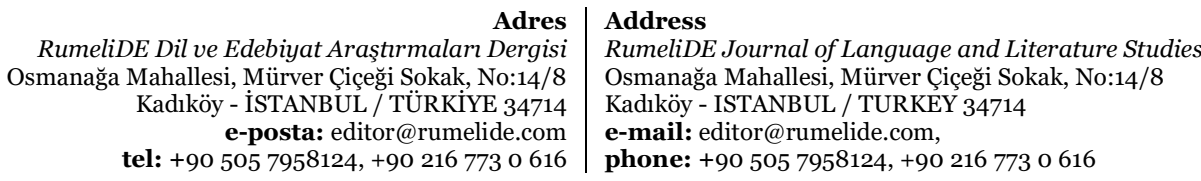


adlandırılan bu kesim sefalet görmüş, zorluk çekmiş ve yaşanılamayacak derecede kötü şartlardaki konutlarda barınmak zorunda kalmışlardır. Bu halk, İskân Komisyonu tarafından adaya yönlendirilmiştir. Adadakilerin yardımıyla lüks konutlara yerleştirilen "Anadolu muhacirleri" bu konutlarda yaşamakta zorluk çekerler. Konutların ihtişamı karşısında şaşkınlığa uğradıkları gibi buralarda yaşamaya alışmadıkları için onları kullanmaya bile kıyamazlar. Hatta daha da ileri giderler, eşyalarını dışarı çıkarıp dışarıda yatıp kalkmak isterler. Bu davranışlarının en önemli nedeni; değişik köylerden kovulduktan sonra tekrar hükümet eliyle böylesine lüks saraylardan da bir gün çıkartılarak evsiz barksız kalacaklarına yönelik duydukları kaygıdır. Bunu duyan adalılar onların düşüncelerinin yanlış olduğunu ısrarla onlara anlatmaya çalışırlar. Özellikle Salman Sami onları ikna edebilmek için asker üniformasını giyer, onları bir alanda toplayarak konuşma yapar. "Anadolu muhacirlerinin" önderi konumundaki Kara Elif, düşüncelerinde ısrarlı olduklarını yineler:

"Bak, kurban olduğum doktor, iyisin has konuşuyorsun ya bizi bu güzel, her biri bir saray gibi evlerde barındırmazlar. Kara kışın ortasında gelirler, bu evler sizin neyinize eeey çingenelerden beter çılaklar, siktir olun derler, bizi götürürler, kepir taşlı ot bitmez bir dağın yamacına iskan ederler. Sen iskan nedir biliyor musun, altın yürekli doktor paşam." (Tanyeri Horozları, 2019: 346).

$\mathrm{Bu}$ durum göçmenlerin geçmişte yaşadıkları olumsuz olaylardan kaynaklı duydukları güvensizlik ve bunun da yaşanılan mekâna karşı kaygı dolu gözlerle yansımasıdır. İnsan topluluğunun elinde olmayan nedenlerden dolayı zaman zaman zorunlu olarak göçe tabi tutulması kendilerinde her an için yaşadıkları ortamı terk edeceği algısı oluşturmuştur. Böylece diken üstünde yaşama hissiyatının yaşanması kaçınılmaz bir hâl almaktadır.

Kara Elifin sözleri onların kaygllarını özetler niteliktedir. Adalılar biraz daha diretince muhacirler evlerine çekilir; ancak yine de kaygılıdırlar. Yaşanan savaşlar, yapılan antlaşmalar ve göç insanlarda hem intibak hem de gelecek kaygısına neden olur. Bu durum, mekânsal kaygılara yol açar.

Kaygı kimi zaman umutlu bekleyişe de zemin hazırlar. Bu bekleyiş, haber alınamayan şahısların yolunu gözlemek konusunda olduğu gibi mekân için de söz konusudur. Göç edenler, terk ettikleri yer ve yurtlarının özlemi içinde yaşam sürerken hep ülkelerine dönme umudu içindedirler. Yurtlarına geri dönüp dönemeyeceklerine yönelik bir belirsizlik söz konusu olduğu için aileler kaygılıdırlar. Girit'ten Türkiye'ye göç ettirilmiş olan Musa Kazım Ağa yurduna dönebilmek için can atmaktadır. Daha önce de ifade ettiğimiz gibi bu yöndeki bazı girişimleri sonuçsuz kaldığı hâlde kendisi hala umutludur, bir yandan da kaygılı bir bekleyiş içindedir. Bir Ada Hikayesi dörtlüsünün son serisi Çıplak Deniz Çiplak Ada'da Musa Kazım Ağa bu durumu açıç̧a belirtir:

"Bizim Yunanistan'da çok başka arkadaşlarımız da var. Onlar ne eder, ne yaparlar beni buralardan alır Giride sağ salim kızlarımla götürürler.

(...)

İnsan ne olursa olsun, başına ne gelirse gelsin, insan umudunu kesmemeli. Yalnız kalmış, umudunu yitirmiş insan yarı ölü bir insandır." (Çıplak Deniz Çıplak Ada, 2019: 53).

İnsanoğlu doğup büyüdüğü vatanına aynı zamanda bir kimlik benliğiyle bağlıdır. Uyruğu altında bulunduğumuz ülkenin vatandaşı olduğumuzu belgeleyen kimlik kartlarımız sadece resmi bir kağıt olmanın ötesindedir. Çünkü birey ülkesiyle ve vatanıyla bir benlik oluşturmuştur. Ülkesiyle kimi zaman sevinmiş, kimi zaman gülmüş ve kimi zaman da ağlamıştır. Bu nedenle göç eden topluluk her ne kadar gittiği ülkede mutlu ve huzurluysa da bu benlik algısı ve bağlanma hissi onlarda özleme ve geri dönme umuduna yol açmıştır. Romanda anlatıcı özellikle bu durumu hayatiyet kazandırdığı karakterlerin sözleriyle inandırıcı kılmaya çalışmaktadır.

\footnotetext{
RumeliDE Dil ve Edebiyat Araştırmaları Dergisi Osmanağa Mahallesi, Mürver Cicçeği Sokak, No:14/8 Kadıköy - İSTANBUL / TÜRKIYE 34714 e-posta: editor@rumelide.com tel: +90 505 7958124, +90 2167730616 
Romanda sadece dışarıdan adaya gelen halk değil, adada yaşayan Yunan karakterler de yerlerinden edilmek istemez. Bu karakterlerden biri, ada halkı tarafindan sevilen ve saygı duyulan Hiristo Reis'tir. Ada halkı ve balıkçılar onun ayrılmasını istemedikleri gibi Hıristo Reis de Türkiye'yi terk etmek istemez. Mübadelenin ne anlama geldiğini bilmeyen ada balıkçlarına Hıristo Reis, şöyle anlatır:

"Mübadele çok insanın ocağını söndürdü, çok insanı hasta etti, çok insan aklını oynattı." (Karıncanın Su İçtiği, 2018: 205).

Bireyin yaşayacağı en temel korku "ölüm korku"sudur. Diğerleri, ölümü çağrıştırdığı için bir alt korku kategorisinde değerlendirilebilir. Romanda mübadiller yaşadığı/yaşayacağı belirsizliklerden dolayı kaygılansalar da aynı zamanda bu göçün kendi hayatlarına mal olacağı düşüncesiyle kaygının yanında korku da yaşamışlardır.

Bir Ada Hikayesi dörtlüsü, zorunlu olarak göçe tabi tutulan farklı etnik grupların yaşadıkları zorluk ve sıkıntılı hâllerin mekânla ilişkilendirilerek anlatıldığı seridir. Adaya yerleşenler, yaşamlarının önceki dönemlerinde savaş yaşamış, katliamlara şahit olmuş, işkenceler görmüş ve sürgüne uğramış; kısacası çeşitli olumsuzluklardan sonra adaya yerleşmişlerdir. Adanın ilk dönemlerinde ıssız görünümü korku ve kaygı yaratsa da zamanla yaşanılan çirkinliklerden uzaklaşarak bu olumsuz olayları yaşamak istemeyen topluluğun hayal ettiği bir mekân karşımıza çıar. Adaya yerleşen karakterlerin konuşmalarından, tavır ve davranışlarından artık huzur içinde yaşama isteğinde oldukları anlaşılmaktadır. Adada yaşayan topluluğun karşılıklı yardımlaşma içinde olması, birbirlerinin hak ve hukuklarına riayet etmeleri, evsiz ve barksız ailelere çıkar gözetmeksizin konut temin etmeleri buranın insanın yaşamak isteyeceği ütopik bir mekâna dönüşmesini sağlar.

\section{Sonuç}

Yaşamımız boyunca korku ve kaygı duygusu bizlerle birlikte olmaya devam edecektir. Sosyal hayatta bu iki kavram; korku ve kaygı sı sık birbirinin yerine kullanılmakta, birbiriyle karıştırılmaktadır. Çalışmamızda da belirttiğimiz gibi korku bilinen bir yerden, tehlike arz eden durumlarda ve nesnesi olan unsurların bizlerde yarattı̆̆ı duyguyken kaygı herhangi bir tehlike arz etmeyen; ancak belirsizlikten kaynaklanan bir huzursuzluk duygusudur. İnsanoğlu yaşamı boyunca korku ve kaygıyı değişik boyut ve şekillerde yaşar. Bu duyguları kimi zaman canımıza kastedildiğinde, kimi zaman bir toplulukta ve kimi zaman da yabancı bir mekândayken yaşarız.

Bilindiği üzere bireysel ya da toplu olarak göç eden insanlar, bir anda kendilerini değişik bir gelenek, görenek, kültür ve kısacası yaşam içerisinde bulur. Yaşanan göç, özellikle antlaşmalar gereği ülkelerin dayatması sonucu belli bir etnik grup ve topluluğa uygulandığı takdirde bu durumun ortaya çıkardığı dramatik sonuçlar topluluğu daha da bir etkilemektedir. Ülkesine vatandaşlık bağıyla, benliğiyle ve aidiyet duygusuyla bağlı olan topluluklar, yeni yerleştikleri ülkelerin dil, din, yaşam tarzı vs. unsurlarına bir anda adapte olamamaktadırlar. Dolayısıyla bu intibak süreci tamamlanana kadar birtakım korku ve kaygıların yaşanmasını da kaçınılmaz kılar.

Yaşar Kemal'in Bir Ada Hikayesi dörtlüsünde korku ve kaygının değişik boyutları gerek olay örgüsünde gerekse de romanın diğer materyal unsurlarında işlenmiştir. Çalışmamızda belli bir zorunluluktan dolayı göç eden toplulukların önceki yaşanmış olumsuz olay ve durumlarını göz önünde bulundurarak yaşadıkları korku ve kaygılı durumları, göç edilen mekâna dair belirsizlik arz eden hususlardan kaynaklı yaşanılan sıkıntıların vermiş olduğu kaygıları, gurbet ve hasret özlemi vs. mekânla özdeşleştirilerek aktarmaya çalıştık.

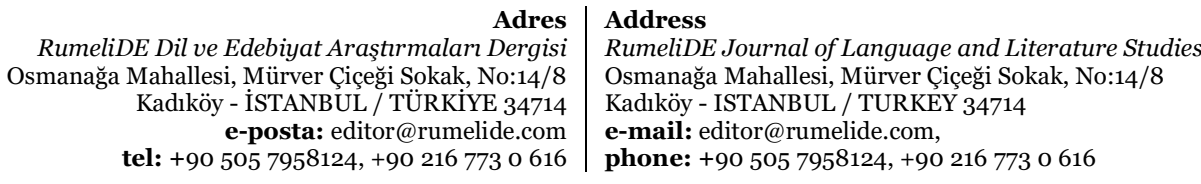




\section{Kaynakça}

Akkayan, Taylan. (1979). Göç ve Değişme. İstanbul: İstanbul Üniversitesi Edebiyat Fakültesi.

Ayyıldız, Mustafa. (2011). Roman Tanım- Tarihçe- Teknik. Ankara: Akçă̆.

Battır, Orhan. (2020). Dünden Bugüne Uluslararası Göç Kuram, Algı ve Siyasa. Ankara: Nobel Akademik.

Çetin, Nurullah. (2019). Roman Çözümleme Yöntemi. Ankara: Akçă̆.

Kemal, Yaşar. (2019). Furat Suyu Kan Akıyor Baksana 1. İstanbul: Yapı Kredi.

Kemal, Yaşar. (2018). Karıncanın Su İçtiği 2. İstanbul: Yapı Kredi.

Kemal, Yaşar. (2019). Tanyeri Horozları 3. İstanbul: Yapı Kredi.

Kemal, Yaşar. (2019). Çıplak Deniz Çıplak Ada / Bir Ada Hikayesi 4. İstanbul: Yapı Kredi.

Kierkegaard, Soren. (2017). Kaygı Kavramı. (Çev: Türker Armaner.). İstanbul: Türkiye İş Bankası Kültür.

Korkmaz, Ramazan ve Şahin, Veysel (Ed.). (2017). Romanda Mekân, Ankara: Akçağ.

Svendsen, Lars Fr. H..(2017). Korkunun Felsefesi. (Çev: Murat Erşen.). İstanbul: Redingot.

Watt, Ian ve Barthes, Roland. (2006). Gerçekçilik ve Romansal Biçim. (Çev: Mehmet Sert.). İstanbul: Yirmidört.

Tepebaşll, Fatih. (2019). Roman İncelemesi. Konya: Çizgi.

Yalçın, Meral Gezici. (2017). Göç Psikolojisi. Ankara: Pharmakon.

Yaman, Fatih. (2019). Göç ve Toplum. İstanbul: Ketebe.

Yönlü, Kübra Yücel. (2018). Göç Sosyolojisi. İstanbul: Doğu. 